\title{
PRESIDENTIAL SUCCESSION AND DISABILITY
}

\author{
Ruth C. SILva*
}

Last February, when President Eisenhower announced his candidacy for reelection, he again urged the Congress to clarify that section of the Constitution that provides for the exercise of presidential power when a President is disabled. In view of the President's two illnesses, presidential succession and disability were important-although not greatly discussed-issues during the campaign. A year ago, Congressman Emanuel Celler released the replies he had received to a questionnaire dealing with the problem of the President's inability to exercise the powers and discharge the duties of his office. The questionnaire sought opinion on procedures to be followed if such an emergency should arise. Replies to the questionnaire were conflicting and confusing. The suggestions offered included proposals to empower the Congress, the Supreme Court, the National Security Council or some special commission to determine when a President is disabled. ${ }^{1}$

As was pointed out at the time of President Eisenhower's heart attack, twice before a President of the United States had been in ill health and his infirmity had a marked effect on national policy. The Constitution provides that the powers and duties of the Presidency shall devolve upon the Vice President in case of the President's inability to discharge them and that an officer designated by Congress shall act as President in case of removal, death, resignation, or inability of both the President and Vice President. ${ }^{2}$ The Constitution does not, however, expressly answer the three major questions that concerned Congressman Celler's subcommittee: What is the status of one who acts as President because of the inability of the President? What constitutes inability to discharge the powers and duties of the presidential office? Who is to determine when an inability exists and when it ceases? It is submitted that the Celler committee failed to get consistent answers to these three questions because the committee chose to ignore altogether the more basic problem of presidential succession.

The Vice President or officer designated by Congress may be called to act as President either because of vacancy in the office of chief executive or because of the incumbent's disability. In case of death, resignation, or removal, the presidential

* A.B., A.M. 1943, Ph.D. 1948, University of Michigan. Teaching Fellow, University of Michigan, 1944-46; Instructor, Wheaton College (Mass.), 1946-48; Fulbright Professor, Fouad ler Univ., Cairo, Egypt, 1952-53; Associate Professor of Political Science, The Pennsylvania State University, since 1948. Author, PResidentrar Succession (195r). Contributor to legal and political science journals in this country and abroad.

${ }^{1}$ House Committee on the Judiciary, Presidential Inability, 84th Cong., 2d Sess. (1956); N. Y. Times, Feb. 10, 1956, p. r, cols. 7-8. •

${ }^{3}$ U. S. Const. art. II, $\S$ I, cl. 6. 
office is vacant; and, consequently, the problem of restoring the President to his powers does not arise. In case of disability, however, the Presidency is not vacant; and, therefore, the problem of restoring executive powers to the President is presented. This unavoidably raises questions relating to presidential status and tenure: Does the successor become President? What is the status of the disabled President? Is the President to resume the exercise of presidential power when his inability passes?

Soon after Vice President John Tyler succeeded to presidential power in $\mathrm{I} 84 \mathrm{r}$, Senator William Allen, of Ohio, objected to establishing the precedent of the Vice President's becoming President upon the death of the latter because he thought that it would unnecessarily complicate the situation on some future occasion when a President became disabled. ${ }^{3}$ In the only two serious cases of presidential inability to date, the Vice President was not called to act as President because of the fear that he would become President and thereby supersede the disabled President for the remainder of the term. As a result, the affairs of the executive branch were allowed to drift. In effect, there was no chief executive. The problem of providing for the exercise of presidential power during a period of inability would not be solved by the enactment of a statute by means of which the disability could be decided. Unless the President's supporters were certain of his status following the inability, they would probably resist any attempt to establish inability, regarding it as equivalent to an action for removal of the disabled President from office. The first question, therefore, is whether or not one who acts as President becomes the President by virtue of the powers and duties devolved upon him.

Study of the records of the Federal Convention shows that it was never intended that the Vice President or designated officer should become President under the succession clause. When the draft Constitution went to the Committee of Style, it contained two provisions dealing with presidential succession, one providing that "the Vice President shall exercise those [the presidential] powers and duties," and the other empowering Congress to designate an officer to "act as President" in certain cases. Each was modified by an adverbial clause limiting the tenure of the acting President to the duration of the inability. The Committee of Style, which was authorized to put the draft into clear and concise language but not to alter substantive provisions, substituted "the same" for "powers and duties" and "devolve" for "exercise"; so that the Constitution, as reported by the Committee, provided that "the same shall devolve on the vice-president" and that the designated officer "shall then act as President." All other records of the Convention similarly indicate the intended antecedent of "the same" as used in the succession clause to be "powers and duties of the said office" rather than "said office." Thus, the argument that the presidential office, rather than its powers and duties, devolves on the Vice Presi-

\footnotetext{
${ }^{3}$ Cong. Globe, 27th Cong., Ist Sess. 4-5 (1841).

'See note 6 infra. For a more detailed consideration of the framing of the succession clause, see Ruth C. Silvia, Presidential Succession 4-r3 (I95I).

3 Max Farrand, Records of the Federal Convention of I787, 600, 625 (I9II and I937); 2 id. I46, 172, 186, 495,499 .
} 
dent, who thereby becomes President, has no foundation in the records of the Constitutional Convention.

Again, it was the efforts of the Committee of Style at consolidation which resulted in combining the two succession provisions and in using the limiting clause, "until the disability be removed," only once, instead of using it to modify each of the preceding clauses separately. The Committee changed the semicolon to a comma, however, so that the limiting clause would be part of a continuous sentence and, therefore, refer alike to the succession of a Vice President and an "officer" designated by Congress. ${ }^{6}$ Other provisions of the Constitution lend support to this interpretation. It is not once said that the Vice President shall become President but rather that he shall act as President, that the presidential powers shall devolve upon him and that he shall exercise the office of President. ${ }^{7}$ The delegates to the ratifying conventions and Hamilton in The Federalist used the same guarded language. ${ }^{8}$ If any of them had thought that the President's successor would actually become the President, it would have been easier to have said "become President" than to have engaged in this circumlocution.

Seemingly oblivious to the intent of the Constitution, all seven Vice Presidents who succeeded to presidential power have taken the presidential oath and have been generally recognized as the de jure President of the United States. William Henry Harrison was the first President to die in office; and it was then decided that the Constitution provided that Vice President John Tyler should become the President and serve until the end of the term for which Harrison had been elected. Exactly how and by whom the decision was made is uncertain; but all evidence indicates that the cabinet, whose ranking member was Daniel Webster, a constitutional lawyer of no small repute, so decided. ${ }^{9}$ Although Tyler thought himself qualified to exer-

'The draft appears in the left column and the clause as reported in the right:

Art. $\mathrm{X}, \S 2:$ ". . . and in case of his removal as aforesaid, death, absence, resignation or inability to discharge the powers or duties of his office the Vice President shall exercise those powers and duties until another President be chosen, or until the inability of the President be removed." Art. $\mathrm{X}, \S \mathrm{I}$ : "The Legislature may declare by law what officer of the United States shall act as President in case of the death, resignation, or disability of the President and Vice President; (semicolon) and such Officer shall act accordingly, until such disability be removed, or a President shall be elected." 2 id. 575, 573.

${ }^{7}$ U. S. Const., art. I, $\S 3$, cl. 5 ; art. II, $\S \mathrm{I}$, cl. 6 ; Id., XII and XX.

${ }^{8}$ Amendment proposed by the New York Convention, 2 Jonathan Eiliot, Debates in the Severar States 408 (2d ed. 1866); Mason, Madison, and Monroe, 3 id. 487-90, 498; Martin, 1 id. 378 . Tur Federalist No. 68, at 427-28 (Lodge ed. 1892 ).

${ }^{\circ}$ Silva, op. cit, silpra note 4, at I4-3x; 2 George Ticknor Curtis, Life op Daniel. Wessten $67 n$ (1870). Thomas Ewing III, the grandson of Harrison's Secretary of the Treasury, wrote in a letter to the N. Y. Times, Dec. I0, I921, p. I2, col. 7: "Mr. Webster expressed the opinion that even though the President survived the period of inability and became capable of performing the duties of his office during the term for which he was elected, he could not displace the Vice President who had assumed 
cise presidential power without any oath other than the one he had taken as Vice President, he took the presidential oath so doubt could not arise concerning the legality of his acts as chief executive. ${ }^{10}$ Apparently Webster thought this was the proper procedure, because he offered the resolution in 1850 for the two Houses to assemble for the administration of the presidential oath to Millard Fillmore. ${ }^{11}$

Not all of Tyler's contemporaries approved of the decision that he had become President. Many of the newspapers at the time viewed him merely as the Vice President who was acting as President. Although they did not object to his taking the presidential oath, no one argued that the taking of this oath actually made him the President. ${ }^{12}$ Among those who agreed that Tyler had not become President were John Quincy Adams and Henry Clay. ${ }^{13}$ Clay must have changed his mind, however, for he voted with the majority eight weeks later, when both houses of Congress, over the strong opposition of John McKeon, William Allen, and Benjamin Tappen, recognized Tyler as President of the United States. ${ }^{14}$ Within a few weeks after Congress approved Tyler's succession, the whole matter was practically forgotten.

The precedent set by Tyler has since been confirmed six times. The status and

the duties of that office." Then speaking of President Wilson's illness, Attorney Ewing said: "If that opinion is correct there can be no temporary displacement of the President. This of course adds greatly to the seriousness of the step in the event that the President has not died but is merely incapacitated." At the time Ewing wrote this letter, he possessed over seventy boxes, barrels, and suitcases of his grandfather's papers. These papers are now in the possession of the Library of Congress but have not been sorted, indexed, or made available for research purposes. In 1947, Dr. Elizabeth McPherson, a member of the Library's staff, examined six letter books, 2000 unbound letters, and a sixtyfive page journal covering the period of the elder Ewing's service in the Harrison-Tyler cabinet, but found no reference to presidential succession. Whether the younger Ewing based his letter to the New York Times on these papers is not known; but correspondence with the Ewing family confirms that he was thoroughly familiar with the papers.

104 James D. Richardson, Messages and Papers of the Presidents 31-32 (1897); Herbert W. Horwil, The Usages of the American Constitution 70-71 (I925); 2 Lyon Tyler, The Letters and Times of the Tylers 12 (I885); Samuel Tyler, Memoir of Roger Brooke Taney 295-296 (1872); Peter R. Levin, Seven by Chances Accidental Presidents $27-28$ (I948).

11 Webster's resolution provided that both Houses assemble for the administration of the oath "prescribed by the constitution to the late Vice President of the United States, to enable him to discharge the powers and duties of the office of President of the United States, devolved on him by the death of Zachary Taylor. . . ." S. Jour., 3Ist Cong., Ist Sess. 444 (I850). Webster's phraseology, "late Vice President," implies that he thought Fillmore was already President even though he had not yet taken the oath. The most nearly correct view probably is that the taking of the oath does not make anyone the President. It is Professor Edward S. Corwin's thesis that taking the oath by one elected to the Presidency does not make the man President but is merely his first duty. Corwin thinks the man is already in office when he takes the oath, and points out that the Constitution says it is the President, not the President-elect, who takes the oath. As Corwin mentions, the Act of March $x$, 1792 assumed that Washington became President on March 4, 1789, although he did not take the oath until April zoth. Corwin, The President 59, 148-49, 34I (1940). In any case, succeeding Vice Presidents must have thought the presidential oath important, for all seven of them took it, and Arthur and Coolidge took it twice. 25 Harper's WeEkLY 660 (x88r); N. Y. Times, Feb. 3, 1932, p. 28, col. 8.

${ }^{12}$ E.g. New York Evening Post (Dem.) and Richmond Enquirer (Dem.) reprinted in 60 Niles National Register I13 (I84I).

13 10 Chardes Francis Adams, Memoirs of John Quincy Adams 463-65 (1874-1877); 12 id. at 176; 2 Lyon TyLer, op. cit. supra note 10, at 30; 2 Calvin Colton, The Works of HenRy Clay $355-56$ (rgo4).

14 Cong. Globe, 27th Cong., Ist Sess. 5 (184r). 
tenure of Millard Fillmore, Chester A. Arthur, Theodore Roosevelt, Calvin Coolidge, and Harry S. Truman have never been seriously questioned. At the time of Andrew Johnson's impeachment, however, his presidential status was disputed; but nobody suggested calling a special election to choose a President who would displace him before the end of Lincoln's second term. The original resolution providing for Johnson's impeachment styled him "Vice-President and acting President of the United States." It seemed necessary, however, to recognize him as the President in order to remove him. ${ }^{15}$ Yet, it was Senator William Pitt Fessenden's conviction that Lincoln's successor had actually become President which prevented Johnson's removal..$^{16}$ Actually, the precedent according to which the Vice President becomes President was confirmed by impeaching Johnson as President. ${ }^{17}$

Such was the established rule of succession in $188 \mathrm{r}$ when the first serious case of presidential inability occurred. During the eighty days of President Garfield's fatal illness, he performed but one official act, the signing of an extradition paper. The daily bulletins of his physicians are sufficient evidence that he was unable to perform the duties of his office. While the President was disabled, there was much urgent business calling for the immediate attention of the chief executive. There were mail frauds; there were officers to be commissioned; the country's foreign relations were deteriorating; but only such routine business as could be handled by the department heads without the President's supervision received attention. ${ }^{18}$ The question that most complicated the problem was whether or not Vice President Arthur would become the President for the remainder of the term if called to act in that capacity during Garfield's illness. Some respected legal opinion held that the Vice President would assume the office in case of inability

${ }^{15}$ If Johnson were the President, Chief Justice Chase would preside; and the President pro tempore of the Senate, Ben Wade, whose vote was necessary for conviction, would be a voting member of the court. If, on the other hand, Johnson were merely the Vice President, Wade would preside and whether he would have a vote or not was questionable. Although Wade would have become the acting President if Johnson had been removed, he not only sat as a member of the impeachment court but also voted for removal. David Miller DeWitt, The Impeachment and Trial of Andrew Johnson I52, 380, 390-93, 553, 576 (1903).

${ }_{18}$ The principal charge against Johnson was that he had violated the Tenure of Office Act by removing Secretary of War Stanton, a Lincoln appointee, without the consent of the Scnatc. The act provided that such removals could not be made without senatorial consent, but an appointee's title to office expired one month after the expiration of the term of the President by whom the officer had been appointed. If Johnson were still Vice President, he had removed Stanton during Lincoln's term and thus had violated the act. If, on the other hand, Johnson had become President, Stanton's tenure had expired, and, therefore, Johnson had not violated the law. Although George S. Boutwell argued that Johnson was the President when the impeachment court was being established, he later argued that the term of office was four years and that the powers and duties, not the office and its term, had devolved upon Johnson. He said Johnson had no term, and it was during Lincoln's second term that Stanton had been removed. Id. at 367-69, 4xx, 424-25. Senator Fessenden's vote was necessary for removal. But the Senator from Maine thought Johnson had become President and, therefore, had not violated the Tenure of Office Act. Consequently, he voted for acquittal. 2 Francis Fessenden, William Pitr FESSENDEN 246-50 (I907).

172 George Boutwell, Reminiscences of Sixty Years in Public Affairs 113 (ig02).

${ }^{18}$ George F. Howe, Chester A. Arthur 152-53, I8I (1934); N. Y. Herald, Sept. I, I881, p. 5, col. 3 , and p. 6, cols. 2-3; id., Sept. 5, I88ז, p. 4, cols. $\mathrm{x-3}$, and p. 6, cols. 2-3; N. Y. Times, Aug. II, I88I, p. I, col. 7 , and p. 4 cols. $2-3$. 
just as in case of vacancy and the powers and duties once devolved could not be returned to the President when the disability was removed.19 Although the great weight of opinion favored the President's resumption of his powers and duties if and when he recovered, ${ }^{20}$ the cabinet was impressed by the arguments to the contrary.

When it appeared that Garfield would recover, the cabinet met and discussed the inability question. There was unanimous agreement on the desirability of having Arthur act as President during Garfield's recuperation; but four of the seven cabinet members thought there could be no temporary devolution of presidential power on the Vice President. In view of this conflicting opinion, the cabinet concluded that it would be unfair to advise Garfield to invite Arthur to act as President without first presenting all of the questions for the President's consideration because it might mean that they were asking the President to abdicate for the rest of the term. All agreed that the President was too ill to have these questions presented to him. The cabinet thought that the shock of taking any action on the matter might cause his death. Consequently, the whole matter of succession and inability was dropped. ${ }^{21}$ Garfield's death made it unnecessary to solve the dilemma in I88I; and the problem was not raised again until Wilson fell ill in Igrg.

Wilson's inability was probably more detrimental to the public interest than was Garfield's, not only because it lasted longer, but also because it occurred during the struggle over the League of Nations. There can be no question that Wilson was unable to perform his presidential duties much of the time from September 25, I9I9 to March 3, I92I. During the special session of the Sixty-sixth Congress, twenty-eight acts became law due to the President's failure to pass on them within the requisite ten days. ${ }^{22}$ Wilson did not meet his cabinet for eight months during his illness. ${ }^{23}$ The Senate Commttee on Foreign Relations was unable to get any word or action from the President on the matter of the Shantung Settlement. ${ }^{24}$ The Constitution says that the President shall receive the representatives of foreign states, but Viscount Grey, the British Ambassador, spent four months in Washington

${ }^{10}$ E.g., Dwight, Presidential Inability, 133 No. Am. Rev. 436 (1881); former Judge Abram J. Dittenhoefer, quoted in the N. Y. Herald, Sept. $13, x 88 \mathrm{I}$, p. 5 , cols. $\mathrm{I}-2$.

${ }^{20}$ E.g., Butler, Presidential Inability, 133 No. Ax. Rev. 428 (x881); Cooley, Presidential Inability, id. at 422; Trumbull, Presidential Inability, id. at 417; Curtis, Presidential Inability, 25 HARPER's WEERLY 63r (r88r); former Attorney General Jeremiah Black, Governor Alfred H. Littlefield, of R. I., and Governor Hobard B. Bigelow, of Conn., quoted in the N. Y. Herald, Sept. 6, I88r, p. 5, col. I; Judge Lyman Trumbult, id., Scpt. 9, r88r, p. 8, col. 4; Judge (N. Y. S. Ct. 3d Jud. Div.) and Attorney General A. Schoonmaker, Jr., of New York, id., Sept. I7, I88I, p. 6, cols. I-2.

${ }_{21}$ Pittsburgh Post, Sept. 3, I881, p. I, col. 2; N. Y. Tribune, Sept. 2, I88r, p. 5, col. 2. On Sept. 5, I88I, the Pittsburgh Post (p. I, col. 3) reported that Secretary of State James G. Blaine, Secretary of the Navy William H. Hunt, and Secretary of War Robert T. Lincoln thought the Vice President could temporarily act as President; but Attorney General Wayne MacVeagh, Posmaster General Thomas L. James, Secretary of the Treasury William Windom, and Secretary of the Interior Samuel J. Kirkwood were of the contrary opinion.

${ }^{20}$ Rogers, The President's Illness, if Am. PoL. Scr. Rev. 87 (1920).

232 David Houston, Eight Years With Wilson's Cabinet 69-70 (ig26); David Lawrence, The True STORY OF WoOdrow WiLson 298 (I924).

${ }^{34}$ N. Y. Times, Oct. I4, I9I9, p. I, col. 7 . 
without seeing the President once. ${ }^{25}$ At one time, Senator Gilbert M. Hitchcock, the Democratic leader in the Senate, thought he might be able to get the Republicans to compromise on the Versailles Treaty, but Wilson's physicians refused to let him see the President, and, as Hitchcock said, he had to consult with the President before the Democratic Senators could do anything. ${ }^{2 B}$ Although it was reported five days later that Hitchcock had seen the President three times, ${ }^{27}$ it was plainly evident that there was a disabled President in the White House. Many students of the period agree that public business in general, the fate of the treaty in particular, was affected by the President's isolation from public opinion, from his advisers, and from congressional leaders. ${ }^{28}$

Public affairs were conducted much as they had been during Garfield's illness. Either presidential powers and duties were not discharged or were handled in such manner as the cabinet, the President's family, and his personal entourage could devise. There seems to be almost unanimous agreement that state papers were given to Mrs. Wilson first. If she had any doubt concerning the effect they would have on her husband, she submitted them to Dr. Cary T. Grayson, Wilson's physician. If Dr. Grayson thought the President was strong enough to pass judgment on them without injuring his health, they were shown to him. If not, they were deferred or passed on to Secretary of the Treasury David Houston or to a few others in whom Mrs. Wilson had confidence. ${ }^{29}$ That this situation existed was rather widely known at the time; yet there was no serious movement of the devolution of presidential power on Vice President Thomas R. Marshall.

The possibility of inviting Marshall to act as President was discussed several times. On March I, I920, the House Committee on the Judiciary held hearings on three bills and one proposed constitutional amendment for the declaration of such an inability. The hearings served only to bring out almost insurmountable constitutional problems, the most difficult of which was whether the President could be restored to his powers and duties when he recovered. Authorities were cited on both sides of the question, but the Committee could reach no conclusion and reported none of the measures. ${ }^{30}$ At another time, the Senate Committee on Foreign Relations sent Senators Albert Fall and Gilbert Hitchcock as a special subcommittee to interview the President and determine the truth or falsity of the many rumors

${ }^{25}$ Horwill, op. cit. supra note io, at 80-8r.

${ }^{20}$ N. Y. Times, Nov. 30 , 1919, p. I, col. 4 .

${ }^{27}$ Id., Dec. 5, rgrg, p. I, cols. 6-7.

${ }^{28}{ }_{4}$ Charles Sexmour, The Intimate Papers of Colonel House 506-07, 509-12 (I928); LaWRENCE, Op. cit. supra note 23, at 299; EDITH G. REID, WOOdrow WILSON 224-30 (1934); WILLIMM ALLEN WHIT, WOODROW WiLSON 448-50 (1925); JOHN K. WINKLER, WOODROW WILSON 286-99 (1933).

${ }^{29}$ Mrs. Wilson herself confirms much of this. Edrrt Bolling Wilson, MY Memoirs 288-90 (1938), as does David Houston, the cabinet member in whom Mrs. Wilson had the most confidence. 2 Houston, op. cit. supra note 23, at 60-66. See also Irwin Hoover, Forty-Two YeArs in the White House 105-06 (I934); LAWRENCE, op. cit. supra note 23, at 283-309; Re1D, op. cit. supra note 28, at 224-30; WINkLER, op, cit. supra note 28 , at 287-88. See especially Joseph P. TuMULTy, Woodrow Wilson as I KNEw Him 437-38 (rg21).

${ }^{30}$ Hearings before Committee on the Judiciary on H. R. 12609, 12629, 12647, and H. I. Res. 297, 66th Cong., 2d Sess. (I920). 
that he was in no physical or mental condition to attend to important public business. They were with the President forty minutes, found him in bed but mentally alert; and the visit came to nothing. ${ }^{31}$

The cabinet also considered asking the Vice President to act as President; but the White House circle fought the move. ${ }^{32}$ When Secretary of State Robert Lansing suggested this possibility, Joseph P. Tumulty, the President's secretary, was indignant and reproached Lansing for his lack of devotion to Wilson. Tumulty quotes himself as saying: ${ }^{33}$

You may rest assured that while Woodrow Wilson is lying in the White House on the broad of his back I will not be a party to ousting him. He has been too kind, too loyal, and too wonderful to me to receive such treatment at my hands.

Tumulty's objection to the devolution of executive power on the Vice President seems to have been based on the thought that it would displace Wilson. The President apparently took the same view. Tumulty quotes Wilson as declaring on the occasion of Lansing's forced resignation: ${ }^{34}$ "Tumulty, it is never the wrong time to spike disloyalty. When Lansing sought to oust me, I was upon my back. I am on my feet now and I will not have disloyalty about me."

Because of the fear that a succeeding Vice President would displace the disabled President, the cabinet, in Garfeld's case, and the White House circle, in Wilson's case, decided on the basis of personal loyalty to the disabled President that no disability existed. And both decisions were contrary to fact. The usage by which the Vice President is transformed into a President has practically nullified the constitutional provision for the administration of executive power when a President becomes incapacitated. It is important, therefore, to consider the reasoning by which the precedent has been sustained in case of the President's death, and by what logic it has been extended to the case of his inability.

In substantiation of the thesis that the Vice President becomes President when there is a vacancy or inability in the superior office it is said that the Constitution itself provides that the presidential office, not merely its powers and duties, shall devolve upon the Vice President. ${ }^{35}$ The argument runs that not only is this true grammatically, but that the framers of the Constitution intended it to be the case. In answer to this assertion, it can be pointed out that syntactically "the same," as

${ }^{32}$ N. Y. Times, Dec. 6, rgr9, p. , col. 5. See also Hitchcock's account of this incident, John M. Mathews and Clarence A. Berdaht, Documents and Readings in American Government imi-i 3 (1928).

32 Houston, op. cit. supra note 23, at 37-39; Tumulty, op. cit. supra note 29, at 443-46.

${ }^{33}$ Id. at 443-44 (emphasis added).

${ }^{34}$ Id. at 445 (emphasis added). In 1885 , Wilson wrote that the Vice President's importance consists in that he may cease to be Vice President. Woodrow Wilson, Congressional Government 240-4I (1885). See also REID, op. cit. supra note 28 , at 223 .

${ }^{35}$ For a general exposition of the thesis that the Vice President actually becomes President, see, for example: Wise and Walker, Cong. Globe, 27th Cong., Ist Sess. 4-5 (I84I); Jones, I3 Cong. Rec. 142 (188I) and $\mathrm{I}_{4}$ id. at 918 (1883); Hannis Taylor, 57 CoNG. Rec. 28 (r918); Justice Samuel B. Blatchford's dictum in Merriam v. Clinch, I7 Fed. Cas. No. 9460, at 7o (S. D. N. Y. 1867). See also note I9 supra. 
used in the succession clause, may refer to "powers and duties of the said office" as well as to "said office." In reply to the contention that the framers of the Constitution intended the office as well as its powers and duties to pass to the Vice President, it is necessary only to point to the records of the Federal Convention. ${ }^{37} \mathrm{Al}-$ though the framers of the Constitution intended "the same shall devolve on the Vice President" to be equivalent to "the Vice President shall exercise those powers and duties," the difference in language used in the two parts of the succession clause is frequently cited to buttress the proposition that a Vice President becomes President when called to act as such. It is claimed that in case of single vacancy, the office devolves upon the Vice President for the remainder of the term, but in case both the Presidency and Vice Presidency are vacant, the designated officer acts as President ad interim.

It has been asserted that the adverbial clause, "until the disability be removed, or a President shall be elected," modifies only the clause providing for an officer to act as President. Some have even gone so far as to say that the limiting clause is separated by a semicolon from the clause providing for the succession of the Vice President and refers, therefore, only to the officer who might be designated to act as President. In consequence, they argue, once the Vice President succeeds, he takes the office without limitation for the remainder of the term. It is absurd to hold that the adverbial clause, "until the disability be removed," limits the tenure of a designated officer who acts as President but does not apply to the Vice President who becomes President. As the New York Tribune asked editorially: What kind of sense does it make to say that, if the President becomes ill, the Vice President replaces him for the rest of the term; but, if the Vice President who has suceeded the President also becomes ill, he can resume the exercise of presidential power when he recovers? ${ }^{38}$

Some have tried to escape this conclusion by arguing that the office devolves on the Vice President in case of vacancy in the Presidency, but in case of disability, only its powers and duties devolve on him for the duration of the inability. ${ }^{30}$ The difficulty is that the Constitution makes no distinction between the status of one who succeeds because of vacancy and of one who succeeds because of inability.

\footnotetext{
${ }^{30}$ It is a rule of Latin grammar that the immediately preceding noun is the antecedent of the relative that follows, in which case "the same" would refer to "office." Accepted English usage, however, does not always conform to this rule, nor did it in the period when the Constitution was written. In English the antecedent is frequently the last grammatical unit used as a substantive, in which case the antecedent would be "powers and duties of the said office." 8 Jasies MurRay, A New English Dictionary on Historical Principles (Pt. 2) 75 (1933).

${ }^{37}$ For a general exposition of the thesis that the successor docs not become President, but merely acts in that capacity, see, for example: McKeon, Allen, and Tappen, Cong. Globe, 27th Cong., Ist Scss. 3-5 (184I); Maxey, 13 Conc. Rec. I29 (188x); Lapham, I4 Conc. Rec. 918 (1883); Davis, Inability of the President, S. Doc. 308, 65th Cong., 3d Sess. (1918); Leavitt, A Solution of the Presidential Inability Problem, 8 A. B. A. J. 189 (1922).

${ }^{38}$ Aug، 16, 188r, p. 4, col. 3 .

${ }^{80}$ E.g., Cooley, supra note 20, at 422-424; Curtis, Presidential Inability, 25 HARPER's WEEkLY 583 (I88I); Fulton, Presidential Inability, 24 ALBANY L. J. 286-287 (I88I); the colloquy between Representatives Walsh and Fess, Hearings, supra note 30 , at 40.
} 
The same thing devolves in both cases. ${ }^{40}$ Others have tried to evade this difficulty by saying that the Vice President becomes President in case of inability just as in case of vacancy, but ceases to be President when the disability is removed. ${ }^{41}$ The trouble with this position is that it creates the anomaly of two Presidents at once or necessitates the removal of the disabled President. It also requires the removal of the second President at the termination of the first President's inability; yet the only method for removal of a President from office is impeachment by the House and conviction by the Senate.

If one holds that a succeeding Vice President does not become President, he is not troubled by these inconsistencies. ${ }^{42}$ He does not have to explain why seven "Presidents" have had a term of less than four years while the Constitution provides a four-year term for the President unless he dies, resigns, or is removed before the expiration of that term. There is no need for distinguishing between a Vice President upon whom presidential power devolves and an officer who acts as President. There is no need for distinguishing between vacancy and inability. In all cases, the successor merely acts as President ad interim. This view greatly simplifies the problem of handling cases of disability because it allows the Vice President to act as President for the duration of the inability without displacing the President or without causing the anomaly of two Presidents. This allows the Vice President to discharge the presidential functions as a part of his vice-presidential duties and to do so under his oath as Vice President. As Senator Elbridge G. Lapham said in I883, the Vice President commits himself to faithfully discharge the duties of the office of Vice President, one of which is to perform the functions of the Presidency when they devolve upon him because of vacancy or inability in the superior office. ${ }^{43}$

The objection to this interpretation of the succession clause is that the Constitution vests executive power in the President and, thus, by implication, forbids its exercise by anyone who is not actually the President. The Constitution commands that the President shall take care that the laws be faithfully executed. Specific grants of executive power are made to him. Attorney General Caleb Cushing thought the President, the man holding the presidential office, and he alone, could exercise the executive powers specifically granted in the Constitution, that the act of signing and

\footnotetext{
${ }^{10}$ None of the various drafts of the Constitution distinguished between the status of one who succeeds in case of vacancy and of one who succeeds because of inability, nor is there anything in the records of the Convention to indicate that such a distinction was intended. All of the records show that the devolution of power was intended only for the duration of the inability. 3 FARRAND, op. cit. stipra note 5, at 600; 2 id. at I72, I86, 495, 499, 532, 535, 573, 598-99, 659.

1 E.g., former Judge Elias Griswold, quoted in the N. Y. Herald, Sept. 9, r88r, p. 8, col. 5.

${ }^{12}$ For a more detailed consideration of the law and logic of the presidential succession precedent, see Silva, op. cit. supra note 4 , at $31-47$ and $67-8 x$.

${ }^{13}$ I4 Cong. REc. 9I8-9I9 (1883). The Constitution requires the President to take the oath; but in case of an acting President, one may ask whether his taking the oath is a legal obligation or mere custom. It seems to be assumed that the taking of the presidential oath is a prerequisite to the exercise of presidential power and transforms a Vice President into a President; but it is contended at the same time that the officer designated by Congress would not become President, although, presumably, the same oath would be a prerequisite to his exercise of presidential power also. See stipra note II.
} 
vetoing bills was a personal act of the President and could not be exercised by any other person. ${ }^{44}$ Although the Supreme Court has upheld the delegation of certain powers by the President to the department heads and has said that their acts are presumed to be his and are binding within the sphere of the President's legal and constitutional authority, ${ }^{45}$ the courts have denied to anyone the right to exercise for the President a power which from the nature of the case requires the President's personal judgment. ${ }^{46}$ A study of the cases in which the delegation of executive power has been upheld will show that, in every case, the power in question was one granted to the President by statute. Not once has the Court upheld the delegation of power vested directly in the President by the Constitution. As Professor Edward S. Corwin says, the Constitution knows a single executive power, that of the President, whose duty it is to see that the laws be faithfully executed, a duty which legally is equivalent to the obligation and power to execute them personally. ${ }^{47}$

The argument that the vesting clause, as interpreted by the courts, requires one to become President in order to exercise those powers vested in the President alone is not unanswerable. The restrictions laid down by the courts apply to the delegation of executive power by the President to his subordinates and should not by analogy be extended to the devolution of this power in such a way as to defeat the purpose of the succession clause. The records of the Federal Convention give no indication that the framers of the vesting clause intended to preclude the possibility of an acting President in case of vacancy or inability in the Presidency. Their sole purpose in writing the vesting clause appears to have been the establishment of a single, as contrasted with a plural, executive. ${ }^{48}$ The purpose of the succession clause seems to have been to provide a substitute for the President in certain cases, not to provide for the creation of another President. The rule is well established that the different clauses should be given effect and reconciled if possible. ${ }^{40}$ The conclusion is, therefore, that the clause vesting executive power in the President should be construed in such a way as to allow for an acting President who will exercise executive power in case of the President's removal, death, resignation, or inability until the disability passes or another President is elected.

Obversely, the succession clause should be interpreted in a manner which will

17 Ops. Atr'y GeN. 464-70 ( 1855 ).

t5 7 Ops. ATt'y Gen. 453, 460 (1855). Wilcox v. Jackson, 38 U. S. (13 Pct.) 498, 513 (1839); United States v. Eliason, 4I U. S. (I6 Pet.) 291, 302 (1842); Williams v. United States, 42 U. S. (I How.) 290, 296-97 (1843); Confiscation Cases, 87 U. S. (20 Wall.) 92, 109 (1874); Wolscy v. Chapman, Ior U. S. 755, 769-70 (1879); Runkle v. United States, 122 U. S. 543, 557 (1887); United States v. Fletcher, I 48 U. S. 84, 88-9I (1893); United States ex rel. French v. Weeks, 259 U. S. 326, 334 (1922).

${ }^{40}$ Ex parte Field, 9 Fed. Cas. No. 476r, at 5 (D. Va. 1862); Runkle v. United States, supra note 45 at 557; United States v. Page, 137 U. S. 673, 680-81 (1891); United States v. Flctcher, supra note 45 at $88-91$.

${ }^{17}$ CoRwin, op. cit. supra, note $\mathrm{I} \mathrm{I}$, at $76-82,35 \mathrm{I}-53$.

${ }^{18}$ I Farrand, op. cit. stipra, note 5 , at $21,63,70,72,73,79,88,90,92,93,96,105,106,109,225$, $230,236,244,247,254,26 \mathrm{r}, 266,272,292 ; 2$ id. at 22, 29, 100-01, 116, 132, 134, 135, I $45, \mathrm{I} 58,17 \mathrm{r}$, I85, 40I, 572, 597,657; 3 id. at 132,$347 ; 4$ id. at 17,46 .

"9 Schick v. United States, 195 U. S. 65,68 (1904). 
give effect to the purpose of the vesting clause. This means that there can be no partial devolution of executive power on a Vice President or on a statutory successor while some of this power continues to be exercised by the President. Senators James B. Beck and Richard Coke, Attorney John Brooks Leavitt, and former President William Howard Taft suggested that the extent of the power which devolves is measured by the nature and and duration of a President's inability ${ }^{50}$ It seems, however, that the vesting clause precludes such an interpretation of the succession clause. As George Ticknor Curtis pointed out during the illness of President Garfield, executive power is a unit and is vested entirely in one man. This means that if the incumbent of the office cannot discharge all of its powers and duties, although he may be able to discharge some of them, either all or none of the said powers and duties devolve on his successor. ${ }^{51}$ Since it is the purpose of the vesting clause to create a single executive, ${ }^{52}$ and since constitutional provisions are not to be nullified without regard to the aims and objects of the instrument and the principles on which it is based, ${ }^{53}$ we must reject an interpretation of the succession clause that would split the exercise of executive power. The proper view seems to be that executive power is a unit, a continuing power unbroken by succession-that there be one person legally authorized to exercise this power at all times, although he may not always be the incumbent of the presidential office and may not always have a term of four years.

It has been suggested that judicial interpretation of the vesting clause in cases involving the delegation of executive power prohibits the exercise of certain executive powers by an acting President. It has also been suggested that such a power as the veto power is vested in the President alone, and, consequently, such powers

${ }^{\text {to }}$ At the time of Wilson's trip to Europe, former President William Howard Taft suggested that Wilson could exercise the foreign relations power in Paris. If an emergency arises, Taft said, Vice President Marshall, in his capacity as acting President, could exercise those powers related to domestic affairs which Wilson's foreign duty prevented him from exercising. 57 CoNG. Rec. I19-20 (I9I8). See the remarks of Beck and Coke, 13 Cong. Rec. 124 and 140 (188I), respectively; and Leavitt, stupra note 37, at 190. Leavitt said in 1923, shortly after President Harding's death, that the Presidency is too heavy a responsibility for one man, and he attributed Harding's death to this fact. Leavitt suggested that the succession clause provides for the partial devolution of presidential power on the Vice President when the pressure of multifarious duties causes a partial inability on the part of a President. Leavitt said that all a President needs to do in order to secure the Vice President's help is to ask for his assistance, in which case those duties which the President is unable to perform will devolve on the Vice President. N. Y. Times, Aug. II, r923, p. 8, col. 7. Presidential candidate Thomas E. Dewey suggested in 1948 that the Vice President might be made a kind of assistant President. It seems, however, that the Vice President would always act for the President, in his name, and subject to his direction. Consequently, the principles involved would be agency and delegation rather than devolution.

${ }^{51}$ Curtis, supra note 39 , at 583 . Curtis thought that, since this was true, the inability of a President to discharge any of his powers was an "inability" within the meaning of the succession clause and all of his powers should then devolve on the Vice President. See also Cole, To What Extent Can the President of the United States Perform the Duties of His Offie While Abroad?, 4 Mass. L. Q. 180, 193 (Igrg); Miller, Some Legal Aspects of the Visit of President Wilson to Paris, 36 HARv L. REv. 5I, 78 (I922).

"2 See note 48 supra; also The Federalist, op. cit. supra note 8, Nos. 70 and $7 \mathrm{I}$ at $436-50$.

${ }^{6}$ Aldrich v. Kinney, 4 Conn. 380, 385 (1822); People v. Dawell, 25 Mich. 247, 26r (1872). 
would be dormant during periods of vacancy or inability in the presidential office. ${ }^{54}$ Such a doctrine must be disallowed because executive power can never be dormant. The public welfare requires that there be someone at all times to exercise this power. In law, executive power is a continuing one which never ends and which is not broken by succession. This power can never be allowed to lapse. All executuve powers, therefore, may be exercised by a Vice President or statutory successor during periods of vacancy or inability. Furthermore, his acts have behind them all the force of the constitutional and statutory provisions in effect at the time. ${ }^{55}$

If it is recognized that the Vice President does not become President in case of the President's disability, the problem of what constitutes inability is less formidable, since the disabled President would not be thought to have forfeited his office. Nearly all of those who hold that the Constitution provides only for an inability of a permanent character extending throughout the remainder of the term hold also that, once the inability is established, the Vice President becomes President for the unexpired portion of the term. If the Vice President actually displaces the incapacitated President for the duration of the term, only the most extended disabilities should be held to fall within that class of inabilities which devolve presidential power on the Vice President. If the Vice President merely acts as President for the duration of the inability, however, restriction to inabilities extending throughout the entire term seems unnecessary. Moreover, this view relieves us from trying to be prophets who will determine whether an ill President will recover and precisely how long his recuperation will take.

Even if duration is ruled out as a limitation on the meaning of inability, there is still no unanimous agreement on the definition of this word. Some hold that it is limited to mental incapacity, while others believe it covers any disability, whatever the cause. During Garfield's illness, there was an impressive body of opinion that held that the only disability recognized by the Constitution was intellectual incapacity. Theodore Dwight, Professor of Constitutional Law at Columbia College, applied the common law which defined the term as mental inability. He said that it was such an incapacity as a civil court would recognize as unfitting a man to make a grant, but not including physical disability, such as an arm injury making it necessary to have a deputy sign for him. ${ }^{56}$ Former Senator William W. Eaton, a recognized authority on the Constitution, stated that the succession clause provided for no disability of which the President could be aware and was amazed at

${ }^{64}$ In $188 \mathrm{x}$, Senator Maxey of Texas implied that these powers were dormant by insisting that the veto power was vested in the President alone and cannot be exercised by an acting President and yet insisting also that one who exercises executive power under the succession clause is merely the acting President. I3 CoNG. Rec. I28-34 (188x).

${ }^{50}$ McCluskey v. Hunter, 33 Ariz. 513, 5I8-I9, 266 Pac. I8, 20 (I928); Barrett v. Duff, II4 Kan. 220, 223, 217 Pac. 918, 919-20 (1923); State ex rel. Matson v. O'Hern, 104 Mont. 126, 152, 65 P. $2 d$ 619, 631 (1937); In te An Act Concerning Alcoholic Beverages, 130 N. J. L. 123, 129, 31 A. 2d 837, 840 (1943); Ex parte Hawkins, to Okla. Crim. 396, 399-400, I36 Pac. 991, 993 (1913); Ex parte Crump, Io Okla. Crim. 133, 144-53, 135 Pac. $428,433-36$ (1913).

${ }^{80}$ Dwighr, op. cit. sipra note 19 , at $436-39$. 
the suggestion that the President could decide his own disability. The "inability," he held, must be one such as insanity, which is patent to everyone except the President. As long as the President possesses reason, said Eaton, he is not disabled in the constitutional sense. ${ }^{57}$ Secretary of the Interior Samuel J. Kirkwood likewise thought the Constitution provided only for mental inability, an opinion with which Senator Joseph E. McDonald, of Indiana, Governor Shelby M. Cullum, of Illinois, and Judge Lyman Trumbull agreed..$^{58}$

There is an equally respectable body of opinion that holds that inability is not restricted to mental incapacity. If the public interest suffers because the President is unable to exercise his powers, whatever the cause, a case of inability exists. Benjamin Butler, writing with reference to Garfield's illness, said that inability is obvious to any right thinking person. If an emergency arises and the President is unable to act, the Vice President is to assume presidential power. ${ }^{59}$ Among those who have thus broadly defined "inability" are Congressman George M. Robeson, Judge Elias Griswold, Senator Elbridge G. Lapham, George Ticknor Curtis, and Attorney John Brooks Leavitt. ${ }^{60}$ There is an abundance of conflicting opinion on the meaning of the term, but none is authoritative. The records of the Federal Convention and the commentators on the Constitution throw no light on the question. Since there are no authorities to whom one can turn for a definition of "inability," the term must be defined on the bases of general principles of law and rules governing constitutional interpretation.

To restrict the meaning of inability to mental incapacity would deprive the United States of a chief executive in case of the President's physical disability, on his capture by the enemy in time of war, and on other occasions when the President is mentally competent, yet physically unable to exercise his powers. A definition of inability that fails to provide for the exercise of executive power at all times is contrary to the legal principle that executive power is a continuing one, never ending, never dormant, never allowed to lapse, and that there must be someone at all times to exercise the power. ${ }^{61}$ The courts say that where words admit different meaning, the one consonant with the object in view is to be selected, that words are to be taken in their obvious sense and not in a sense unreasonably restricted, and that the Constitution must receive a practical construction. ${ }^{62}$ These well-established rules point to a definition of "inability" that covers all cases in which the President is, in fact, unable to exercise a power that the public interest requires to be exercised.

${ }^{67}$ N. Y. Times, Sept. 2, I88I, p. I, col. 3.

${ }^{t 8}$ Kirkwood, Boston Evening Transcript, July 16, 1881, p. 2, col. 3; McDonald, id., Aug. 19, 188r, p. 2, col. 2; Cullum and Trumbull, New York Herald, Sept. 9, 188x, p. 8, col. 4 .

${ }_{\text {to }}$ Butler, supra note 20, at 428-30. See also Cole, op. cit. supra note 5I, at 194.

${ }^{\circ 0}$ Robeson, N. Y. Tribune, Sept. 2, I88I, p. 5, col. I; Griswold, supra note 4I; Lapham, I4 Cong. Rec. 919 (1883); Leavitt, supra note 37, at 190 and his letter to the N. Y. Times, Dec. 6, 1921, p. I8, col. 6; Curtis, supra note 39, at 583.

${ }^{01}$ See note 55 supra.

23 Pollock v. Farmers' Loan and Trust Co., 158 U. S. 601, 618 (1895); Railroad Co. v. Peniston, 85. U. S. (18 Wall.) 5, 31 (1873); see note 53 supra. 
The cause and duration of the inability are immaterial; the question is one of fact.

This conclusion would mean that some illnesses and absences are inabilities, while others are not. In time of war, for example, an illness of a few days may be more serious than one of several months at another time. With the development of rapid communication and transportation, absence would not usually be an inability in fact. Although the records of the Philadelphia Convention show that the Vice President was intended to exercise presidential power during the President's absence, usage has established that mere absence from the United States is not a disability within the meaning of the Constitution. ${ }^{63}$ This is not to say, however, that some absences might not be inabilities. The answer in a particular case would depend on the facts. Even if Congress possesses the power, it probably cannot define inability before its occurrence in such a way as to cover every contingency. ${ }^{64}$ The most Congress can do is to declare that the term "inability" shall cover all cases in which the President is in fact unable to exercise the powers and discharge the duties of his office. The only effect of such a declaration would be to put congressional approval on well-established principles of law and constitutional interpretation and to guide those who must determine if an inability exists in a particular case.

The final problem concerns who shall decide when a disability on the part of the President exists. The records of the Constitutional Convention do not reveal the intention of the framers of the succession clause on this subject. John Dickinson raised the question, but none of his colleagues offered an answer. ${ }^{\text {65 }}$ In I88I, when President Garfield was incapacitated, the great weight of opinion favored the theory that the successor is to determine when the President is disabled. Adherents of this position say that the Vice President is obligated to exercise the power and perform

${ }^{03}$ The succession clause as referred to the Committee of Style provided for five cases: removal, death, absence, resignation, and inability. 2 FARRAND, op. cit. stipra note 5, at 575. The provision for the exercise of presidential power during the President's absence was deleted by the Committce, which had no authority to change substantive provisions; and there is no record that the Convention was aware of this change. 2 id. at 598-99. Since absence is not specifically mentioned in the Constitution, the question is whether or not it is covered by the term "inability." For a consideration of this question, see SiLvA, op. cit. stipra note 4 , at $92-98$.

${ }^{4}$ There has never been unanimous agreement on the power of Congress to deal with inability. One position is that the only power granted to Congress is to declare what officer shall act as President in case of vacancy or inability in both the Presidency and Vice Presidency, and under tho rule of inclusio unitus, exclusio alteritts, Congress has no other powers in the field of presidential succession. 3 W. W. Willoughby, The Constrtutional LaW of the United States 1467-68 (i929); Butler, supra note 20, at 431-33; Daugherty, Presidential Succession Problems, 42 Forum 523, 525 (1909); Davis, op. cit. supra note 37, at 13-15; Lavery, Presidential Inability, 8 A. B. A. J. 13-17 (1922).

The other position is that the elastic clause gives Congress power to implement the inability clause, since this is a power necessary and proper to carry into execution the executive power and guarantec that it shall not become dormant. 2 JoHn Randolph Tucker (a strict constructionist), The ConstTtUtion of THE UNITED States 713 (1899); Cooley, supra note 20, at 425-27; Curtis, stlpra note 20, at 631 and note 39, at 583; Judge Samuel Shellabarger and Governor John Davis Long quoted in the N. Y. Herald, Sept. 5, 188I, p. 8, cols. I-2; former Attorney General A. Schoonmaker, Jr., supra note 20; Congressman George M. Robeson, supra note 60; former Vice President Schuyler Colfax, N. Y. Tribune, Sept. 8, $188 \mathrm{r}$, p. 5, col. 3; Representative Clifton N. McArthur thought the clastic clause gave Congress the power to define inability just as it gave Congress power to define "interstate commerce" and "intoxicating liquor." Hearings, supra note 30 , at 35.

${ }^{B S}$ Farrand, op. cit. stipra note 5, at 427. 
the duties of the Presidency when the President is disabled, just as it is his duty to preside in the Senate, and no enabling action by the courts, the Congress, the cabinet, or the President is necessary. ${ }^{66}$ Judge Trumbull said there is no need for providing a formal means of determination. In Trumbull's opinion, the inability must be so notorious that no one can reasonably doubt its existence. In such a case, he said, the Vice President is authorized to assume the executive power if important public business requires executive action. When these conditions exist, continued the Judge, the cabinet should notify the Vice President just as in case of the President's death but there is no constitutional requirement for this notification. It is only custom in case of the President's death and desirable in case of his inability. It is extralegal and adds nothing to the Vice President's right to exercise presidential power. ${ }^{67}$

Trumbull is probably correct in saying that the decision belongs to the successor in the first instance. Since the duty of acting as President under certain conditions of fact is imposed upon him, his official discretion extends to the determination of whether the condition exists or not. It is a well-established rule of law that, in contingent grants of power, the one to whom the power is granted is to decide when the emergency has arisen. Thus, the Vice President or the officer designated by law to act as President is constituted the judge of the executive's inability in the first instance and is bound to act according to his interpretation of the facts. Someone must decide whether the President is disabled; and, since the Constitution mentions only the successor, he is the judge of the facts. ${ }^{68}$ If past experience can be taken as a reliable indication of the attitude of future successors, the danger of their usurping the President's powers on the pretext of inability is slight indeed. The judgment of both Vice Presidents Arthur and Marshall was conditioned by their sense of propriety. These two cases indicate that the real problem is not how to guard against the successor's abuse of power, but how to relieve him of the embarrassing duty of taking the initiative.

It seems certain that no court has power to issue a writ of mandamus to the Vice President or designated officer directing him to act as President during the latter's inability because a court can only order the performance of a ministerial function. ${ }^{69}$ Perhaps the courts can pass on the validity of some executive action taken by the successor and thereby indirectly on the inability of the President, if properly raised

${ }^{\circ 0}$ E.g., Butler, supra note 20, at 431-33; Davis, op. cit. supra note 37, at 13-15; Governor Thomas A. Hendricks, N. Y. Herald, Aug. 2I, I88I, p. 7, col. 2; Long, Shellabarger, and Schoonmaker, supra note 64; Congressman George M. Robeson, Boston Evening Transcript, Sept. 2, I881, p. I, col. 6; former Senator William W. Eaton, supra note 57; Senator Augustus H. Garland, I3 Cong. REc. I39 (I88I); Sentor Elbridge G. Lapham, 14 CoNG. Rec. 917 (I883).

${ }^{67}$ Trumbull, supra note 20 , at 420-22.

${ }^{08}$ Martin v. Mott, 25 U. S. (12 Wheat.) I9, 31-32 (I827); Aurora v. United States, II U. S. (7 Cranch) 382 (1813); Field v. Clark, r 43 U. S. 649, 682-94 (189r); Hampton \& Co. v. United States,

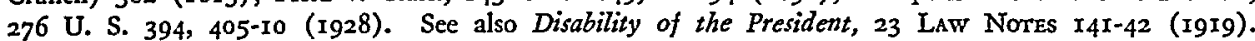

${ }^{60}$ Gaines v. Thompson, 74 U. S. (7 Wall.) 347 (1869); Dudley v. James, 83 Fed. 345 (C. C. D. Ky. 1897); Mississippi v. Johnson, 7I U. S. (4 Wall.) 475 (1867); Carrick v. Lamar, II6 U. S. 423,426 (1886). See also Cole, stupra note $5 \mathrm{I}$, at 194 . 
in a case involving individual rights; ${ }^{70}$ but this would do nothing to alleviate the Vice President's delicate position in making the determination in the first place. Whether Congress has power either to determine actual inability or to provide a means of deciding such cases is questionable. Opinion on the matter is divided, but the weight of opinion seems to be that Congress has no such power. Congress is given the power to name a successor to act as President after the Vice President, and this probably excludes all other congressional power to deal with presidential succession. ${ }^{71}$

The Congress could, however, relieve the successor of the embarrassment of taking the initiative by passing a concurrent resolution requesting him to act as President or by authorizing some officer or officers to inquire into the President's inability and report thereon to the successor. The actual decision would still rest with the successor, where the Constitution vests it, and his decision would not await or be bound by the report. The investigation could properly be made by the cabinet or the National Security Council because the cabinet or Security Council consists of the President's appointees who are not eager to displace him; and these bodies are in the best position to know the facts. Once it is recognized that the successor does not supersede a disabled President for the remainder of the term, the President might usually invite his successor to act for him for the duration of his inability. But if the President could not or would not do so, the successor should decide on the President's inability with or without a report from the cabinet or National Security Council.

This would answer the questions John Dickinson raised in the Constitutional Convention: what is the extent of the term "disability" and who is to be the judge of it? Not only can the inability problem be thus solved, but such a solution would provide for flexibility and speedy action in actual cases of disability and would permit a solution without resort to the difficult process of constitutional amendment. This is the solution likely to be proposed in the Eighy-fifth Congress as the CellerKeating Resolution because it is the solution which accords with the views of the committee's chairman and ranking minority member-Emanuel Celler and Kenneth B. Keating. ${ }^{72}$

\footnotetext{
${ }^{70}$ In cases in which individual rights depend on executive action, the individual has the right to resort to the law for a remedy. Marbury v. Madison, 5 U. S. (1 Cranch) 137, 170 (1803); United States ex rel. Boynton v. Blaine, I39 U. S. 306, 326 (I891); In re Cooper, 143 U. S. 472,503 (1892). But the question must arise in a case involving actual litigants. Clough v. Curtis, I34 U. S. 361,372 (1890). On the other hand, the courts might decide that the question was political and submitted to the successor's discretion alone. If the courts decide this, they will hold that they are bound to follow the successor's decision. Luther v. Borden, 48 U. S. (7 How.) I (1849).

${ }^{71}$ See note 64 supra. It is a well-established rule of construction that enumeration in the Constitution of certain powers denies all others unless incident to an express power and necessary for its cxecution. United States v. Harris, ro6 U. S. 629, 635-36 (r883); 3 Joseph Story, Commentaries on the Constitution of THE UNITEd STATES $\$ 1243$ ( 1833 ).

${ }^{73}$ Hedrings before Special Subcommittee to Study Presidential Inability of the House Committee on: the Judiciary, 84th Cong., $2 \mathrm{~d}$ Sess. 2, 20-2I, 33-34, 46 (1956), and Plan D, id. at 5.
} 